\title{
From the Center
}



$\mathrm{O}$ n October 6, 2003, the Center for Hospitality Research (CHR) at Cornell University, the publisher of the Cornell Hotel and Restaurant Administration Quarterly, started requiring that users register to view its Web site content. On its Web site (at TheCenterForHospitality Research. org), users can download .pdf versions of Reports, Tools for the Hospitality Industry, Working Papers, Case Stud-

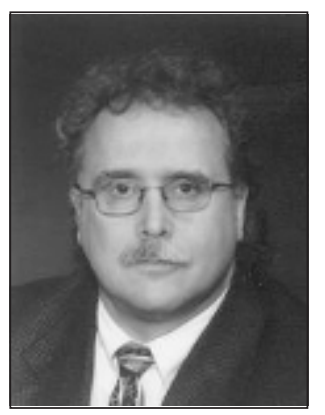

Gary M. Thompson

typically bring new and returning visitors to the site. We find that visitors to the site who came for one report, for example, typically end up perusing a variety of related items on the site.

\section{Who Are the Folks that Register?}

Based on their self-reported job titles, we know the following about the registrants:

- 9.3 percent are CEOs, chairmen, chairperies, and more - all gratis. In the first twelve months, more than sixty-four hundred people have registered, with more than fourteen hundred registering in the month of September 2004. In this editorial, I'll focus on answering three questions: What brings people to the CHR Web site? Who are these folks? and What do they know that you don't?

\section{What Brings People}

\section{to the CHR Web Site?}

When the CHR releases new content, say, a CHR Report, we announce it via press releases to journalists and then via a mass e-mail sent to people who have requested our e-mails. (That is one reason that you might wish to register with us!) These announcements sons, principals, presidents, chairs, owners, partners, or founders;

- 3.4 percent are CFOs, COOs, CIOs, CTOs, SVPs, or VPs;

- 5.0 percent are GMs;

- 11.1 percent are directors or heads;

- 13.9 percent are managers, supervisors, or administrators;

- 3.9 percent are analysts;

- 3.6 percent are professors, lecturers, teachers, or doctors (MDs or Ph.D.s); and

- 18.5 percent are students (41 percent from outside Cornell).

We at the CHR have been pleased with the job level and geographic dispersion of the registrants. To us, it's 
a wonderful validation that our material is relevant and that we are making a contribution to the industry's knowledge.

\section{What Do These People}

Know that You Don't?

We're all looking for things that will help us do our jobs more effectively. Registrants on our site have learned that they can find such content on the CHR Web site. By registering and signing up for our e-mails (no, we won't send you e-mails unless you request it), you'll stay aware of the newest content that's available on the Web site. That means you'll be one of the first to hear about our newest report (for example, the CHR report "Why Discounting Doesn't Work: The Dynamics of Ris- ing Occupancy and Falling Revenue among Competitors" by Cathy Enz, Linda Canina, and Mark Lomanno, which was released in early September 2004) or our newest Tool for the Hospitality Industry (for example, the "Emergency Preparedness Essentials" tool by Rob Kwortnik, which was released in late September 2004). Most months see new content releases. Our next two reports, for instance, which will be released by the time you read this, will deal with using information technology strategically and with critical issues in retaining high-performing employees. Check us out and see if we can't make a difference in how you do your job or how your organization performs. -G.M.T.

\title{
THE CENTER FOR HOSPITALITY RESEARCH
}

Gary M. Thompson, Executive Director, Joseph D. Strodel, Jr., Managing Director Glenn Withiam, Director of Publications Jennifer Macera, Administrative Assistant

\begin{abstract}
About The Center for Hospitality Research
A unit of the Cornell School of Hotel Administration, The Center for Hospitality Research (CHR) sponsors groundbreaking research designed to improve practices in the hospitality industry and publishes the award-winning Cornell Hotel and Restaurant Administration Quarterly. Under the lead of CHR's 35 corporate supporters, experienced scholars work closely with business executives to discover new insights into strategic, managerial and operational issues. To learn more about CHR and its projects, visit http:// www.chr.cornell.edu/.
\end{abstract}

